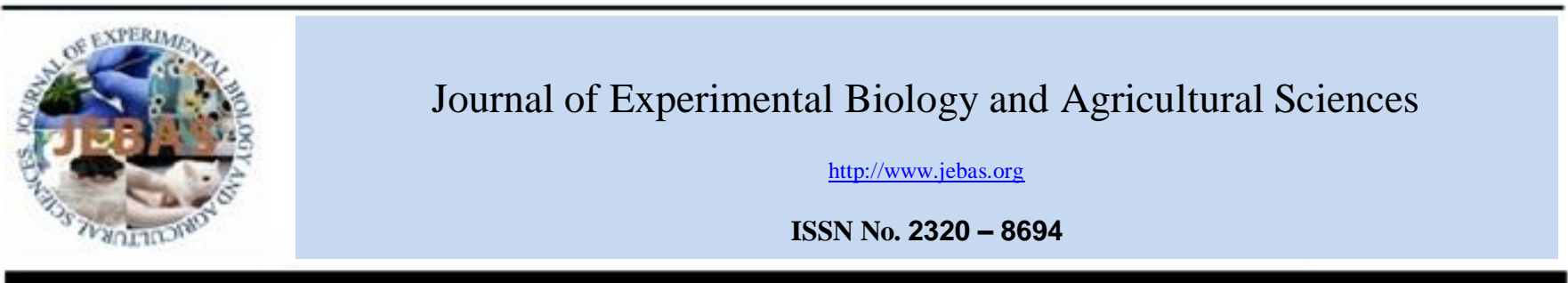

\title{
PISTACHIO (Pistacia vera) BY-PRODUCTS AS RUMINANT FEED: A REVIEW ON PRODUCTION, MANAGEMENT AND UTILIZATION IN ARID AND SEMI-ARID AREAS IN THE MIDDLE EAST
}

\author{
Ashraf Alkhtib $^{1 *}$, Jane Wamatu ${ }^{1}$, Yahya Kaysi ${ }^{2}$, Mohannad Mona ${ }^{3}$, Barbara Rischkowsky ${ }^{1}$ \\ ${ }^{1}$ International Center for Agricultural Research in the Dry Areas (ICARDA), P.O Box 5689, Addis Ababa, Ethiopia. \\ ${ }^{2}$ Damascus University, Faculty of Agricultural Engineering, Department of Animal Production, P.O Box 5735, Damascus, Syria. \\ ${ }^{3}$ General Commission of Scientific Agricultural Research, P.O Box 113, Doma, Damascus, Syria.
}

Received - September 22, 2017; Revision - November 15, 2017; Accepted - November 25, 2017

Available Online - December 27, 2017

DOI: http://dx.doi.org/10.18006/2017.5(6).718.729

KEYWORDS
Pistachio
By-products
Nutritive value
Ruminants

\begin{abstract}
This review presents recent knowledge of the inclusion of pistachio by-products in diets of ruminants. Pistachio harvesting and processing result in considerable amounts of by-products which include hulls (the outer cover of fruit), woody shells (mesocarp), blank fruits, clusters (sometimes referred as twigs) and leaves. The by-products can be preserved by natural drying or ensilaging. This review evaluates pistachio by-products in terms of chemical composition, nutritive value and their effects on ruminant performance and product quality. Their nutritive value is affected by factors which include type of byproduct, pistachio variety, harvesting time and preservation method. Pistachio by-products can use as a source of protein and energy in ruminant feeding to support maintenance and production of meat, milk, wood and hair. Their replacement value in diets of growing, fattening and lactating ruminants ranges between $21-35 \%$. The replacement values of silage from pistachio by-products ranges between 15-24\%. However, the presence of high levels of copper and phenolic compounds in pistachio by-products may restrict their inclusion in high proportions into ruminant diets. There is need for more research on the inactivation of phenolic compounds in pistachio by-products so that they can be fed to ruminants in larger proportions. Further studies are needed to evaluate the effects of pistachio by-products on production and reproduction performance of ruminants as well as product quality. The presence of pesticides, fungicides and phenolic compounds in pistachio by-products necessitate identifying the effect of long term feeding on livestock health.
\end{abstract}

* Corresponding author

E-mail: a.s.alkhtib@gmail.com (Ashraf Alkhtib)

Peer review under responsibility of Journal of Experimental Biology and Agricultural Sciences.

Production and Hosting by Horizon Publisher India [HPI] (http://www.horizonpublisherindia.in/).

All rights reserved.
All the article published by Journal of Experimental Biology and Agricultural Sciences is licensed under a Creative Commons Attribution-NonCommercial 4.0 International License Based on a work at www.jebas.org.

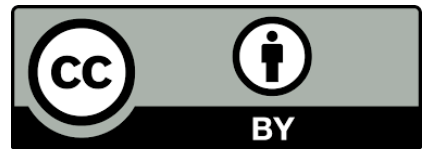




\section{Introduction}

Pistachio (Pistacia vera) kernels have been consumed by human civilizations since prehistoric times (Dreher, 2012). Pistachio kernels contain high concentrations of proteins, unsaturated fatty acids, dietary fibers, potassium, magnesium, vitamin $\mathrm{K}, \gamma$ tocopherol, antioxidants, anti-inflammatories and phytochemicals (Dreher, 2012). Total production of pistachio kernels in the world increased from 397000 tons in 1993 to 1000000 tons in 2012 (FAO, 2014). The major producing countries are Iran (52\%), USA (21\%), Turkey (13\%) and Syria (8\%), (FAO, 2014). Pistachios are well known for drought tolerance. They can survive in arid and semi-arid areas with an annual rainfall of less than $250 \mathrm{~mm}$ (Khabaz \& Meristani, 2013). Middle East is predominantly arid and semi-arid, and growing of pistachio is increasingly being considered as a sustainable solution to desertification (Khabaz \& Meristani, 2013). Pistachio harvesting and processing generates considerable amounts of by-products that include hulls (the outer over of fruit), woody shells (mesocarp), blank fruits, clusters (sometimes referred as twigs) and leaves. In this review, the term "pistachio by-product mixture (PBM)" will refer to a mixture of leaves, clusters and hulls which result from the dehulling process. These by-products are predominantly used as energy sources. While pistachio leaves, twigs and woody shells are predominantly used as domestic energy sources, pistachio hulls $(\mathrm{PH})$ are disposed, thereby decomposing naturally in farmlands. Pistachio harvesting and peeling takes place during summer, between August and October, leading to rapid spoilage of the by-products. This generates unpleasant stench, thus, providing an environment for pathogens and insects which could be harmful to humans, livestock and crops. Pistachio hulls have approximately $60 \%$ of the metabolizable energy of barley grains (Kearl, 1982; Bohluli et al., 2010). Accordingly, worldwide pistachio by-products can be paralleled to about approximately 900000 tons of barley grains, if extensively utilized. Therefore, the use of pistachio by-products for livestock feeding has potential to, not only contribute effectively to solving hygiene problems resulting from spoilage of hulls but also to provide an alternative feed resource of good nutritive value. A review on the utilization of pistachio byproducts as livestock feed would provide guidelines to policy makers, agricultural extension and farmers for better utilization.

\section{Pistachio production and management}

Harvesting and processing pistachio goes through several stages as shown in Figure 1. The biomass from pistachio harvest consists of fruits, twigs and leaves. At harvest, full-ripened fruits are separated from the biomass and peeled. A pistachio fruit consists

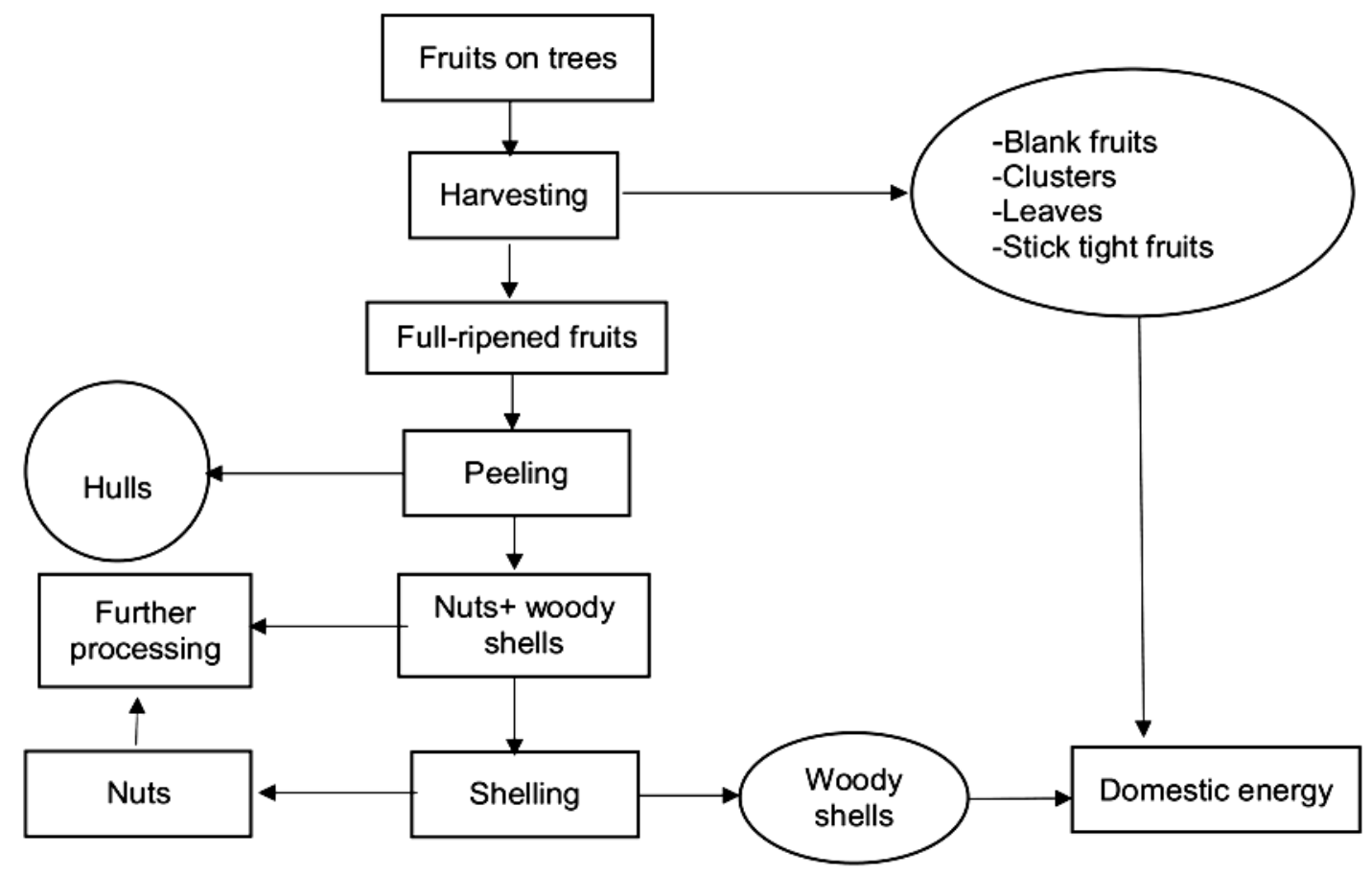

Figure 1 Production of pistachio by-products

Journal of Experimental Biology and Agriculture Science http://www.jebas.org 
of a nut, endocarp, mesocarp (woody shell) and epicarp (hull) (Figure 2) (Dreher, 2012). Hulled fruits are dried and the kernels excluded by shelling the woody shells. Kernels are then packed and marketed. Accordingly, producing one $\mathrm{kg}$ of pistachio kernels is accompanied by production of $1.5 \mathrm{~kg}$ of by-products proportioned as $64.5 \%$ hulls $(\mathrm{PH}), 25 \%$ clusters, $10 \%$ leaves and $0.5 \%$ woody shells (Vahmani et al., 2006; Bagheripour et al., 2008). Other resulting by-products of smaller quantities from the harvest include culled fruits (blank fruits) and unripened fruits. Pistachio dressing ( $\%$ of nut to total fruit weight), $\%$ of blank fruits and $\%$ of leaves are affected by the variety (Table 1 ), climatic and crop management factors (Assimakopoulou et al., 2013; Roosta \& Mohammadi, 2013). Pistachio by-products result in significant waste management problems due to high organic and phenolic content (Acton, 2012). However, there are no effective waste management approaches of pistachio by-products in Middle East countries (Acton, 2012). A simple management strategy is applied by rural farmers in Syria. They use twigs, blank fruits, stick tight fruits, leaves and woody shells as an energy source for domestic use while they dispose hulls to farmlands to naturally decompose. In Iran, $\mathrm{PH}$ are marginally utilized as livestock feed, however, other uses of pistachio by-products include cleaning of waste water and wool dyeing (Acton, 2012) and biogas production(Çelik \& Demirer, 2015). Extensive research has been conducted on the potential of pistachio byproducts as livestock feed. However, the use of pistachio byproducts by farmers for livestock feeding is limited (Acton, 2012).

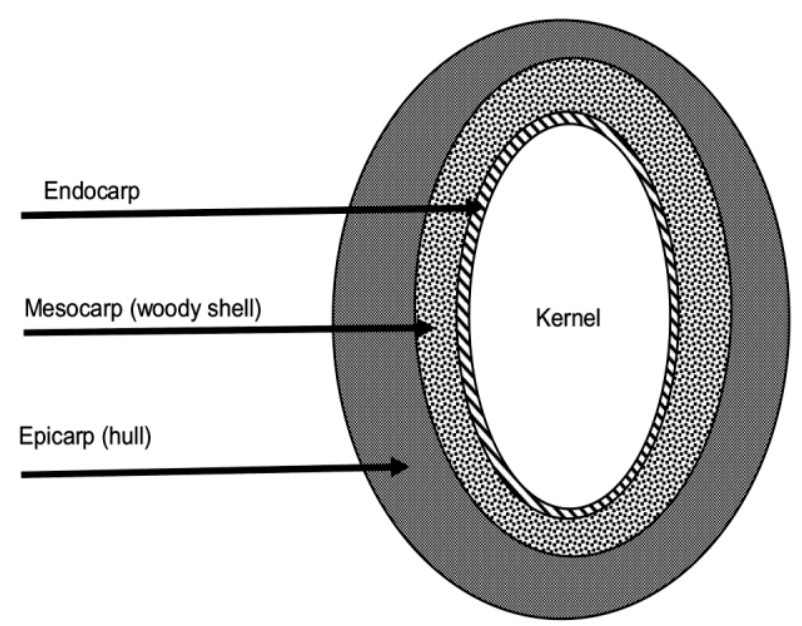

Figure 2 Physical structure of the pistachio fruit

\section{Preservation methods}

After pistachio harvest, green fruits are peeled by small machines which mix fruits with water and remove the hulls (Khabaz \& Meristani, 2013). Wet hulls decay rapidly because of their high content of protein and carbohydrates and hot weather (Khabaz \& Meristani, 2013). As the production of pistachio by-products is seasonal, their use in livestock feeding over the whole year necessitates suitable preservation and storage. It has been reported that sun-drying and ensiling are potential methods to preserve

Table 1 Structure of fruits of different Syrian varieties of pistachio

\begin{tabular}{|c|c|c|c|c|c|}
\hline Variety & Origin & Kernel & Free-kernel fruits $\% *$ & Woody shell & Hulls \\
\hline Ashori* & Syria & 32 & 68 & - & - \\
\hline Ashori† & Syria & 33.8 & 66.2 & 28.1 & 38.1 \\
\hline Abo-Rihah* & Syria & 32 & 68 & - & - \\
\hline Batori* & Syria & 36 & 64 & - & - \\
\hline Batori† & Syria & 35.9 & 64.1 & 25.8 & 38.3 \\
\hline Alemi-Red* & Syria & 40 & 60 & - & - \\
\hline Alemi-Red $\dagger$ & Syria & 39.7 & 60.3 & 21.6 & 38.7 \\
\hline Nab Aljamal* & Syria & 31.2 & 68.8 & - & - \\
\hline Bondoqi* & Syria & 30 & 70 & - & - \\
\hline Jalab-Red* & Syria & 33.3 & 66.7 & - & - \\
\hline Ajami* & Syria & 40 & 60 & - & - \\
\hline Lazawardi* & Syria & 30.7 & 69.3 & - & - \\
\hline Alemi-White* & Syria & 38 & 62 & - & - \\
\hline
\end{tabular}

*:Source:Khabaz \&Meristani, 2013, $\dagger:(A C S A D, 1988)$

Journal of Experimental Biology and Agriculture Science http://www.jebas.org 
pistachio by-products. Pistachio by-products are produced during summer which facilitates sun drying. Satisfactory silage prepared from PBM with a $\mathrm{pH}$ of 4 has been reported (Bagheripour et al., 2012; Elahi et al.,2012). Decreasing total phenols and increasing digestibility of pistachio was achieved by increasing ensiling time and adding polyethylene glycol (Bagheripour et al., 2012; Elahi et al., 2012). Polyethylene glycol binds to tannins and decreases its negative impact on rumen microbial activity. Adding culled date fruits to fresh $\mathrm{PH}$ during ensiling at a ratio of 1 to 5 decreased total tannins and phenolic compounds (Soltaninezhad et al., 2016). Some anaerobic genera of bacteria such as Bacillus, Lactobacillus, Streptococcus have been reported to have the potential of degrading phenolic compounds (Tahmourespour et al., 2016). Culled date fruits are rich in sugars. They might enhance the activities of anaerobic bacteria which have the ability to degrade phenolic compounds. Ensiling pistachio by-products could be a practical method of preservation on small farms. Dry pistachio by-products have high bulk density (Behgar et al., 2008), therefore, drying is appropriate for longtime storage and wide transportation. Preservation method could affect the nutritive value and palatability of by-products, therefore, there is need for further studies on the effects of storage method and duration on dry matter intake and performance of ruminants.

\section{Physical characteristics}

Pistachio hulls have a bulk density of 0.56 , water holding capacity of $4.53 \mathrm{~kg} / \mathrm{DM}$, soluble ash of $88 \%$ of ash, soluble dry matter of $52.5 \%$ of dry matter, $4.9 \mathrm{pH}$ and buffering capacity of $7.07 \mathrm{meq} / \mathrm{l}$ as reported by Behgar et al. (2008). The high buffering capacity may exacerbate ensiling (Fuller, 2004). The water holding capacity of $\mathrm{PH}$ is approximately the same as beet pulp but more than that of alfalfa hay (Behgar et al., 2008). This may allow PH to decrease the occurrence of acidosis, decrease nutrient digestibility and dry matter intake in ruminants but at the same time increase water intake (Fuller, 2004). The bulk density of PH is similar to that of sugar beet pulp (Behgar et al., 2008) but it is higher than alfalfa hay, sunflower hulls and cottonseed hulls. This facilitates PH storage and transportation (Behgar et al., 2008).

\section{Nutritive Value}

\subsection{Chemical composition and digestibility}

The chemical composition and in vitro dry matter digestibility (IVDMD) of pistachio by-products vary according to the type of by-product (Bohluli et al., 2010) (Table 2), variety of tree (Boga et al., 2013) (Table 3 and 4), treatment and the method of storage (Bagheripour et al., 2012; Shakeri et al. 2013) (Table 5). Twigs have the highest fat content $(71 \mathrm{~g} / \mathrm{kg})$ followed by hulls $(57 \mathrm{~g} / \mathrm{kg})$, leaves (38) and woody shells (Bohluli et al., 2010). Hulls have the highest content of CP $(166 \mathrm{~g} / \mathrm{kg})$ followed by PBM $(135 \mathrm{~g} / \mathrm{kg})$, leaves $(124 \mathrm{~g} / \mathrm{kg})$, twigs $(121 \mathrm{~g} / \mathrm{kg})$ then woody shells $(16 \mathrm{~g} / \mathrm{kg})$ (Bohluli et al., 2010). Hulls have the lowest neutral detergent fiber (NDF) content $(250 \mathrm{~g} / \mathrm{kg})$ followed by leaves $(310 \mathrm{~g} / \mathrm{kg}), \mathrm{PBM}$ $(318 \mathrm{~g} / \mathrm{kg})$ twigs $(390 \mathrm{~g} / \mathrm{kg})$ and woody shells $(910 \mathrm{~g} / \mathrm{kg})($ Bohluli et al., 2010). Leaves have the highest content of total phenols and total tannins (139 $\mathrm{g} / \mathrm{kg}$ and $69 \mathrm{~g} / \mathrm{kg}$ respectively) followed by twigs (100 g/kg and $48 \mathrm{~g} / \mathrm{kg}$ respectively), hulls (96 g/kg and 45 $\mathrm{g} / \mathrm{kg}$ respectively) and woody shells (15 $\mathrm{g} / \mathrm{kg}$ and $5 \mathrm{~g} / \mathrm{kg}$ respectively) (Bohluli et al., 2010). The most digestible byproduct is hulls $(770 \mathrm{~g} / \mathrm{kg})$ followed by PBM $(700 \mathrm{~g} / \mathrm{kg})$, leaves $(990 \mathrm{~g} / \mathrm{kg})$, twigs $(600 \mathrm{~g} / \mathrm{kg})$ and woody shells $(220 \mathrm{~g} / \mathrm{kg})$. Hulls have the highest IVDMD (\%) then leaves, twigs and woody shells (Bohluli et al., 2010). In Turkish varieties, the varietal range in $\mathrm{PH}$ was reported as $114 \mathrm{~g} / \mathrm{kg}$ for ash, $77.3 \mathrm{~g} / \mathrm{kg}$ for crude protein (CP), $42 \mathrm{~g} / \mathrm{kg}$ for NDF, $40 \mathrm{~g} / \mathrm{kg}$ for acid detergent fiber (ADF), 6 $\mathrm{g} / \mathrm{kg}$ for condensed tannins, $55 \mathrm{~g} / \mathrm{kg}$ forin vitro organic matter digestibility (IVOMD) and $1.34 \mathrm{MJ} / \mathrm{kg}$ for metabolizable energy (ME) (Boga et al., 2013). The varietal variation in chemical composition of PH and PBM was found among Iranian varieties (Bohluli et al., 2010). It was $30 \mathrm{~g} / \mathrm{kg}$ for ash, $21 \mathrm{~g} / \mathrm{kg}$ for ether extract (EE), $85 \mathrm{~g} / \mathrm{kg}$ for CP, 30g/kg for NDF, $21 \mathrm{~g} / \mathrm{kg}$ for TP and $15 \mathrm{~g} / \mathrm{kg}$ for TT. The range among varieties for PBM was $39 \mathrm{~g} / \mathrm{kg}$

Table 2 Chemical composition of pistachio by-products $(\mathrm{g} / \mathrm{kg})$

\begin{tabular}{|llllllllll|}
\hline \multirow{2}{*}{ By-product } & $\begin{array}{l}\text { \% of total by- } \\
\text { products }\end{array}$ & Ash & EE & CP & NDF & ADF & NFC & TP & TT \\
\hline Hulls & 53.3 & 127 & 57 & 166 & 250 & 200 & 400 & 96 & 45 \\
\hline Twigs & 27.7 & 56 & 71 & 121 & 390 & - & 362 & 100 & 48 \\
\hline Leaves & 9.5 & 92 & 38 & 124 & 310 & - & 432 & 139 & 69 \\
\hline Woody shell & 5.3 & 9 & 3 & 16 & 910 & - & 62 & 15 & 5 \\
\hline $\begin{array}{l}\text { Pistachio by-products } \\
\text { mixture }\end{array}$ & & 92.4 & 53.8 & 135 & 318 & - & 358 & 92.9 & 44.1 \\
\hline
\end{tabular}

*: of the total by-products, EE: ether extract (g/kg), CP: crude protein (g/kg), NDF: neutral detergent fiber (g/kg), ADF: acid detergent fiber (g/kg), NFC: non-fiber carbohydrates (g/kg), TP: total phenolic compounds (g/kg), TT: total tannins (g/kg), Source: Bohluliet al., 2010. 
Table 3 Chemical composition of pistachio by-products according to the variety

\begin{tabular}{|lcccccccc|}
\hline Pistachio v & Ash & EE & CP & NDF & ADF & TP & Total tannins \\
\hline Ohadi & \multicolumn{7}{c}{ Pistachio by-products mixture } & 41 \\
\hline Kaleghuchi & 91 & 87 & 142 & 250 & 205 & 86 & 46 \\
\hline White & 130 & 78 & 94 & 240 & - & 95 & 76 & 34 \\
\hline & 120 & 70 & 166 & 270 & - & & 46 \\
\hline Ohadi & 120 & 57 & 166 & 250 & 200 & 96 & 44 \\
\hline Kaleghuchi & 150 & 78 & 92 & 220 & - & 91 & 75 \\
\hline White & 140 & 57 & 177 & 240 & - & Hulls & 32 \\
\hline
\end{tabular}

EE: ether extract $(\mathrm{g} / \mathrm{kg})$, CP: crude protein $(\mathrm{g} / \mathrm{kg})$, NDF: neutral detergent fiber $(\mathrm{g} / \mathrm{kg})$, ADF: acid detergent fiber $(\mathrm{g} / \mathrm{kg})$, TP: total phenolic compounds (g/kg), source: Bohluli et al., 2010

Table 4 Nutritive value of pistachio hulls of different varieties

\begin{tabular}{|llllllllll|}
\hline Pistachio variety & DM & Ash & CP & NDF & ADF & CT & IVOMD & ME \\
\hline Beyaz Ben & 265 & 167 & 111 & 183 & 155 & 26.3 & 727 & 10.7 \\
\hline Kurmız1 & 267 & 186 & 150 & 190 & 143 & 23.4 & 690 & 10.1 \\
\hline Ohadi & 293 & 114 & 133 & 221 & 183 & 23.7 & 745 & 11.1 \\
\hline Sultani & 285 & 85 & 72.7 & 185 & 154 & 21 & 716 & 10.7 \\
\hline Uzun & 290 & 199 & 108 & 225 & 180 & 25.5 & 716 & 9.76 \\
\hline Keten Gömlegi & 269 & 154 & 145 & 188 & 145 & 20.3 & 702 & 10.3 \\
\hline
\end{tabular}

DM: dry matter (g/kg), CP: crude protein (g/kg), NDF: neutral detergent fiber ( $/ \mathrm{kg}$ ), ADF: acid detergent fiber (g/kg), CT: condensed tannins (g/kg), IVOMD: in vitro organic matter digestibility (g/kg), ME: metabolizable energy (MJ/kg), source: Boga et al., 2013.

for ash, $17 \mathrm{~g} / \mathrm{kg}$ for EE, $72 \mathrm{~g} / \mathrm{kg}$ for $\mathrm{CP}, 30 \mathrm{~g} / \mathrm{kg}$ for NDF, $16 \mathrm{~g} / \mathrm{kg}$ for TP and $12 \mathrm{~g} / \mathrm{kg}$ for TT (Bohluli et al., 2010). Varietal variation in IVOMD of PH among Turkish varieties was $55 \mathrm{~g} / \mathrm{kg}$ (Table 4). Therefore, inclusion of pistachio PBM in the formulation of rations of livestock should consider the variety. Generally, $\mathrm{PH}$, pistachio leaves and PBM have satisfactory chemical composition and digestibility thus they could be used as ruminant feed. Nevertheless, the low protein, low digestibility and high phenolic compounds could limit the use of pistachio twigs and woody shells as feed for livestock. Therefore, it can be suggested that woody shells and twigs be directed for use as energy source or for biogas production. Ruminants are sensitive to intake of fat above $5 \%$ of dry matter in rations (Fuller, 2004). Ether extract content across by-products of various varieties exceeds $50 \mathrm{~g} / \mathrm{kg}$. That would tend to limit the level of inclusion of pistachio by-products into ruminant diets. Therefore, varieties of pistachio which have high content of EE in by-products have high potential to improve unsaturated fatty acids in milk and meat of ruminants. Valizadeh et al. (2009) reported that dry PH has better degradability and digestibility compared to ensiled PH. Shakeri et al. (2013) reported insignificant differences in the nutritive value between dry and ensiled PH. The contradictory results could be due to differences in the source of $\mathrm{PH}$, procedures of drying and ensiling between the studies. The IVOMD of silage from $\mathrm{PH}$ was improved by adding urea and molasses (Valizadeh et al., 2009) and by increasing incubation time (Bagheripour et al., 2008). Urea added to PH during silage preparation might bind to tannins and decrease negative effects on rumen microbes. It has been reported that the activity of tannins is positively associated with the degree of polymerization (Makkar, 2003b). It seems that increasing ensiling time leads to a decrease in the level of polymerization of polyphenolic compounds which leaded to an increase in digestibility. Delgado-Pertinez et al. (1998) reported a reduction in digestibility of dry olive leaves when are stored for longer than 
Table 5 Chemical composition and nutritive value of pistachio hulls

\begin{tabular}{|c|c|c|c|c|c|c|c|c|c|c|c|c|c|c|}
\hline DM & $\mathrm{CP}$ & $\mathrm{EE}$ & $\mathrm{NDF}$ & ADF & ADL & Ash & $\mathrm{TP}$ & $\mathrm{TT}$ & CT & HT & $\mathrm{ME}$ & $\begin{array}{l}\text { Preservati } \\
\text { on }\end{array}$ & Type & References \\
\hline 950 & 125 & 97 & 340 & 246 & 77 & 115 & 140 & 88 & 85 & 40 & - & Sun-dried & PBM & (Babaei et al., 2015) \\
\hline 338 & 91.6 & - & 321 & 210 & 30.4 & 142 & 97.1 & 9.14 & 83.4 & 71.5 & - & $\begin{array}{c}\text { Freeze- } \\
\text { dried }\end{array}$ & PBM & (Bagheripour et al., 2012) \\
\hline 323 & 92.1 & - & 311 & 207 & 28.3 & 141 & 94.1 & 8.91 & 56.1 & 69.1 & - & Silage & PBM & (Bagheripour et al., 2008) \\
\hline 223 & 113 & 78 & 262 & 187 & - & 151 & 82.9 & 44.8 & 49 & 37.9 & 5.86 & Fresh & Hulls & (Bakhshizadeh et al., 2014) \\
\hline 945 & 158 & 69.5 & 250 & 207 & 85.5 & 120 & - & - & - & - & - & Sun-dried & Hulls & (Behgar et al., 2008) \\
\hline 261 & 113 & 110 & 328 & 214 & - & - & 45.3 & 39 & 43 & - & - & Silage & PBM & (Elahi et al., 2012) \\
\hline 910 & 114 & 64.5 & 333 & 206 & - & 127 & 99.5 & 66.8 & & - & - & Sun-dried & PBM & (Ghaffari et al., 2014a) \\
\hline 900 & 153 & 58 & 259 & - & - & 245 & 78.5 & 31.6 & 85 & - & - & Sun-dried & PBM & (Ghasemi et al., 2012a) \\
\hline - & 166 & 57 & 250 & 200 & - & 127 & - & - & - & - & - & Fresh(h) & Hulls & (Gholiezade et al., 2009) \\
\hline 850 & 153 & - & - & - & - & 223 & 112 & 71.3 & - & - & - & Sun-dried & PBM & (Jolazadeh \&Dehghan-Banadaky, 2015) \\
\hline - & 123 & 68.1 & 259 & 220 & 85.6 & 119 & 109 & 73.2 & 43.6 & - & - & Fresh & PBM & (Moradi et al., 2015a) \\
\hline 952 & 218 & 196 & 376 & - & 26.1 & 91 & 44.1 & - & - & - & - & Sun-dried & Hulls & (Naserian et al., 2015) \\
\hline 928 & 115 & 64 & 332 & 206 & - & 121 & 103 & 63.9 & 12 & - & 12.5 & Sun-dried & Hulls & (Razzaghi et al., 2015) \\
\hline 940 & 113 & 65 & 224 & 302 & - & 92 & 66.8 & - & - & - & 8.36 & Sun-dried & Hulls & (Sedighi-Vesagh et al., 2015) \\
\hline 966 & 129 & 57 & 327 & 239 & - & - & 137 & 99.9 & 11.1 & 88.8 & 8.36 & Sun-dried & PBM & (Shakeri et al., 2013) \\
\hline 311 & 130 & 62 & 309 & 226 & - & - & 145 & 101 & 11.4 & 89.4 & 8.36 & Silage & PBM & (Shakeri et al., 2013) \\
\hline 400 & 83 & 45.7 & 335 & 227 & - & 73 & 96.5 & 48.2 & - & - & 10.6 & Silage & PBM & (Soltaninezhad et al., 2016) \\
\hline - & 120 & 50 & 450 & 340 & - & 52 & - & 80 & - & - & - & Fresh & Hulls & (Vahmani et al., 2005) \\
\hline 260 & 120 & - & 210 & - & - & 90 & - & - & - & - & - & Fresh & Hulls & (Valizadeh \&Sobhanirad, 2009) \\
\hline
\end{tabular}

DM: dry matter (g/kg), CP: crude protein (g/kg), EE: ether extract (g/kg), NDF: neutral detergent fiber (g/kg), ADF: acid detergent fiber (g/kg), ADL: acid detergent lignin $(\mathrm{g} / \mathrm{kg})$, TP: total phenols $(\mathrm{g} / \mathrm{kg})$, TT: total tannins $(\mathrm{g} / \mathrm{kg}), \mathrm{CT}$ : condensed tannins $(\mathrm{g} / \mathrm{kg})$, HT: hydrolazable tannins $(\mathrm{g} / \mathrm{kg})$. ME: metabolizable energy (MJ/kg); PBM: Pistachio by-products mixture

4-5 months. Thus, storing dry pistachio by-products is expected to increase degree of polymerization of tannins which might decrease digestibility. Accordingly, increasing storage time of dried pistachio by-products has to be studied as a method of increasing their digestibility. The date of harvest affects chemical composition and digestibility of PH. Labavitch et al. (1982) analyzed PH sampled weekly during harvest time (from the $4^{\text {th }}$ week of August to the first week of October). Hulls produced during the second week of September had comparatively higher $\mathrm{CP}$, fat, soluble sugars and lower total phenols (Labavitch et al., 1982) (Table 6 and 7). That means early and late harvest of pistachio may result in a decrease in nutritive value of $\mathrm{PH}$. A reduction in IVDMD with later harvest dates has been reported and attributed to the increase of NDF and tannins (Labavitch et al., 1982).Use of dry $\mathrm{PH}$ in goat rations up to $32 \%$ did not affect dry matter intake, digestibility of dry matter (DM), NDF and ADF
Table 6 In vitro dry matter digestibility of pistachio by-products

\begin{tabular}{|llcc|}
\hline \multirow{2}{*}{ By-product } & \multicolumn{3}{c|}{ Incubation period/h } \\
& 0 & 12 & 24 \\
\hline Hulls & 520 & 700 & 770 \\
\hline Twinges & 370 & 530 & 600 \\
\hline Leaves & 360 & 620 & 660 \\
\hline Woody shell & 50 & 100 & 220 \\
\hline Pistachio by-products mixture & 510 & 650 & 700 \\
\hline
\end{tabular}

$\mathrm{N}=3$; Source: Bohluli et al., 2010.

but decreased the crude digestibility protein (Sedighi-Vesagh et al., 2015). Dry PH can successfully replace wheat bran in rations 
Table 7 In vitro digestibility of various species of pistachio by-products

\begin{tabular}{|llll|}
\hline By-product & \multicolumn{3}{c|}{ Pistachio varieties } \\
\hline $\begin{array}{l}\text { Pistachio by-products } \\
\text { mixture }\end{array}$ & Ohadi & Kaleghuchi & White \\
\hline DM & $560^{\mathrm{c}}$ & $637^{\mathrm{a}}$ & $610^{\mathrm{b}}$ \\
\hline OM & $580^{\mathrm{c}}$ & $684^{\mathrm{a}}$ & $641^{\mathrm{b}}$ \\
\hline & & & \\
\hline Hulls & & & \\
\hline DM & $635^{\mathrm{a}}$ & $670^{\mathrm{a}}$ & $660^{\mathrm{a}}$ \\
\hline OM & $670^{\mathrm{a}}$ & $719^{\mathrm{a}}$ & $709^{\mathrm{a}}$ \\
\hline
\end{tabular}

$a, b, c=$ means with the same manuscripts in the same line do not defer significantly (P>0.05); Source: Bohluli et al., 2010.

of dairy goats without negative effects on digestibility of nutrients (Naserian et al., 2015). Shakeri et al. (2014) substituted corn silage by PBM silage (6\% or $12 \%$ on DM basis) in diets of calves with no adverse consequences on digestibilities and ruminal fermentation parameters. Treating dry PBM by polyethylene glycol improved DM and CP digestibility (Moradi et al., 2015b).

\subsection{Ruminal Fermentation}

\subsubsection{Rumen pH}

Gholiezade et al. (2009) reported that incorporation of up to $6 \%$ of dry $\mathrm{PH}$ in dairy cattle ration had no significant effect on ruminal $\mathrm{pH}$, however, Gholizadeh et al. (2010) reported higher level of inclusion of dry PH up to $10 \%$ without any effect on rumen pH. It has been reported that consumption of $50 \%$ of $\mathrm{PH}$ in diets of sheep increased rumen fluid $\mathrm{pH}$ (Ghasemi et al., 2012a).Dry PBM may replace alfalfa hay ( $30 \%$ of the dietary DM) in diets of dairy goats without significant effect on ruminal $\mathrm{pH}$ (Gaffari et al., 2014b).Since inclusion of pistachio by-products in diets of sheep increases $\mathrm{pH}$ of rumen fluid, pistachio by-products could be used to reduce acidosis incidence in sheep fed on high levels of concentrates. However, that cannot be applied in cattle as inclusion of pistachio by-products does not increase rumen fluid pH (Gholiezade et al., 2009; Gholiezade et al., 2010).

\subsubsection{Protein metabolism}

Inclusion of up to $6 \%$ and $10 \%$ of dry $\mathrm{PH}$ in dairy cattle ration had no significant effect on blood urea nitrogen and rumen concentration of ammonia-N (Gholiezade et al., 2009; Gholiezade et al., 2010). Ghaffari et al., (2014) are ported a reduction in the concentration of ammonia- $\mathrm{N}$ in rumen fluid as a result of incorporating dry PH in sheep rations at a level of 36\%. Dry PBM replaced alfalfa hay ( $30 \%$ of the dietary DM) in the diet of dairy goats without negative effects on ammonia- $\mathrm{N}$ in rumen fluid (Ghaffari et al., 2014b).

An increase in nitrogen digestibility and nitrogen retention and a decrease in microbial ammonia-nitrogen was reported as a result of dry PBM replacement for lucerne hay (50\% of total dietary DM) (Ghasemi et al., 2012c).Thus, there is a high possibility to use pistachio by-products to decrease ammonia emission from ruminants without negatively affecting protein digestibility. That would decrease ammonia emission to the atmosphere.

\subsubsection{Carbohydrate metabolism}

It has been reported that the use of dry PH 36\% - 50\% (Ghasemi et al., 2012b; Ghaffari et al., 2014a) in sheep rations decreased the concentration of volatile fatty acids in the rumen. Dry PBM replaced alfalfa hay (30\% of the dietary DM) in the diet of dairy goats without any effects on the profile of volatile fatty acids (Ghaffari et al., 2014b). Microbes in the rumen of goats have been reported to have high adaptability to phenolic compounds. That might explain the difference in response of sheep and goats to inclusion of pistachio by-products in terms of carbohydrate fermentation. Total replacement of alfalfa hay (50\% of dietary $\mathrm{DM})$ by dry $\mathrm{PH}$ in the diet of sheep reduced the number and attachment of cellulolytic bacteria to feed particles (Ghasemi et al., 2012a,b).It may be that phenolic compounds of pistachio byproducts bind to proteins of membranes of cellulolytic bacteria in sheep rumen microbe which might result in the decrease in attachment. Bagheripour et al. (2008) reported that in vitro gas production increased as a result of the addition of polyethylene glycol to pistachio by-products which means that tannins in pistachio by-products have potential to inhibit methane production. Adding PBM to corn silage before preparation can decrease in vitro methane production (Denek et. al, 2017). Therefore, optimizing inclusion of pistachio by-product has potential to decrease methane production without compromising digestibility of diets and ruminant productivity.

\subsubsection{Lipids metabolism}

Use of dry PH up to $36 \%$ in sheep ration did not affect the relative abundance of rumen bacteria involved in biohydrogenation (Ghaffari et al., 2014a). Further, Sedighi-Vesagh et al., (2015) indicated that to an increase in polyunsaturated fatty acids content in milk fat of goats as a result of inclusion of dry PBM at level of $32 \%$ of total dietary DM and he related that to a modifications in biohydrogenation of fatty acids in the rumen. However, deeper studies on modifying fatty acid biohydrogenation in the rumen by including pistachio byproducts have to be carried out. 
6 Effect of feeding pistachio by-products on animal performance and quality of products

\subsection{Effects of pistachio by-products on growing ruminants}

Silage prepared from $95 \%$ fresh PBM and 5\% beet pulp can replace $66 \%$ of corn silage corn silage which constitutes $40 \%$ of the diet DM without adverse effect on fattening performance of calves (Frough-Ameri, 2008). Pistachio hulls silage can be included up to $18 \%$ in the ration of growing calves without adverse effect on fattening performance (Shakeri et al., 2013). Feeding growing lambs on silage prepared from a mixture of pistachio hulls and waste dates (in a ratio of 5:1) up to $21 \%$ of the total diet can increase final body weight, weight gain, weights of warm and cold carcass, liver, loin, lean meat, reproductive system, small intestine, and the eye muscle area (Soltaninezhad et al., 2016). Valizadeh et al. (2010) and Norouzian \& Ghiasi (2012) reported that including dry $\mathrm{PH}$ up to $30 \%$ of the ration of growing lambs did not negatively affect fattening performance, carcass characters and mineral content. Supplementation of diets of growing lambs by $500 \mathrm{ml}$ of $\mathrm{PH}$ aqua extract increased nitrogen retention, daily weight gain and decreased feed conversion ratio (Sharifabadi \& Naserian, 2014). Pistachio byproducts mixture replaced alfalfa hay and wheat straw up to $20 \%$ of the total dietary DM with no adverse impacts on feed intake, growth and health of Lambs (Shakeri, 2016). Using soybean meal, treated by $15 \% \mathrm{PH}$ extract, at a rate of $10.5 \%$ of diet DM of growing Holstein bulls improves fattening performance (Jolazadeh \& DehghanBanadaky, 2015).The optimum level of $\mathrm{PH}$ inclusion in rations depends on the basal diet, storage method and chemical composition of $\mathrm{PH}$ and animal type. Generally, inclusion of $\mathrm{PH}$ does not have a positive effect on fattening performance or carcass characters. Tannins decrease ruminal degradation of proteins in the rumen leading to increase in the passerby proteins (Makkar, 2003a). That might increase the influx of essential amino acids to the small intestine which may lead to the improvement in fattening. Tannins might have potential of altering microbial metabolism of proteins and fatty acids which are expected to improve meat content of conjugated fatty acids (Morales \& Ungerfeld, 2015). Thus, further studies need to identify the use of pistachio by-products to improve meat quality of ruminants.

\subsection{Effects of pistachio by-products on milk yield and quality}

The effect of $\mathrm{PH}$ on milk production and composition varies with ruminant species, preservation method and inclusion rate. There is no consensus on the optimum incorporation level of $\mathrm{PH}$ in the ration of lactating ruminants. Several studies have aimed to determine the optimum level of PH in the ration of lactating cattle. The suggested levels as percentage of dry $\mathrm{PH}$ in the total ration DM are 6\% (Vahmani et al., 2005), $10 \%$ (Gholizadeh et al.,
2010), 15\% (Rezaeenia et al., 2012) and 18\% for PH silage (Shakeri et al., 2013). Silage prepared from PBM replaced corn silage up to $15 \%$ of diet DM in dairy cows ration without negative effects on milk yield and chemical composition (Mokhtarpour et al., 2012). Introducing PH to the diet of lactating cows up to $24 \%$ of the total DM did not affect milk yield but increased fat content (Razzaghi et al., 2015). Adding PBM extract to alfalfa silage at a level of $500 \mathrm{~mL} / \mathrm{kg}$ DM also improved milk fat and protein concentrations without any effect on milk yield in goat (Mokhtarpour et al., 2016). Dry PH included in goat ration up to $6 \%$ (Naserian \&Vahmani, 2005) and 32\% (Sedighi-Vesagh et al., 2015 ) with no adverse effect on milk yield and quality. Pistachio by-products mixture replaced alfalfa hay $(30 \%$ of the total diet $\mathrm{DM}$ ) in the diet of dairy goats without affecting milk yield, milk composition, concentrations of short, medium, and long chain fatty acids (Ghaffari et al., 2014b). The inclusion of 32\% dry PBM in the diet of dairy goats had positive effects on fatty acids profile of milk (increase cis-9 and trans-11 CLA and trans-11 18:1) without negative effects on milk yield (Sedighi-Vesagh et al., 2015). Tannins are expected to alter the biohydrogeneation of fatty acids in the rumen leading to an increase in conjugated fatty acids content in milk (Morales \& Ungerfeld, 2015). However, contradictory results have been reported on the effect of using dry pistachio by-products on conjugated linoleic acids in goat milk (Ghaffari et al., 2014b; Sedighi-Vesagh et al., 2015). That could be due to the variation in the duration of storage which may lead to an increase in the degree of polymerization of tannins resulting in an increase of their impact on ruminal hydrogenation of fatty acids. This could also explain the variations in reported optimum levels of inclusion of pistachio by-products in diets of dairy goats and cows.

\subsection{Effects of pistachio by-products on wool and hair production}

The effect of tannins on wool and hair growth is not clear. Terrilla et al. (1992) found that feeding rations containing 5\% of condensed tannins from Sulla had positive effects on wool growth. Conversely, Kumar \& Vaithiyanathan (1990) reported negative effects of tannins on wool growth at the same level of tannins. Moumen et al. (2003) stated that use of dry PH up to $30 \%$ of rations of goat had no adverse effect on Kashmir production and hair follicle traits. Male lambs fed on dry PH up to $32 \%$ of the ration showed no negative consequences on wool growth and traits (Salhi et al., 2009). Feeding growing lambs on PH silage at a level of $25 \%$ of total dry matter intake did not significantly affect wool characteristics but it decreased fleece weight (Salehi \&Mirzaei, 2011). Phenolic compounds in pistachio by-products are expected to alter metabolism of proteins in the rumen which might increase amino acids flux to the small intestine. That is expected to improve wool production and quality. Pistachio by- 
products did not improve Kashmir and wool production in Iranian sheep and goat (Moumen et al., 2003) because Iranian breeds of sheep and goat might have ability to tolerate high levels of phenolic compounds.

\section{Potential toxicities}

Naserian et al. (2015) reported that PH contains $2.6 \mathrm{~g} / \mathrm{kg}$ calcium, $15 \mathrm{~g} / \mathrm{kg}$ of phosphorus and $15 \mathrm{mg} / \mathrm{kg}$ of copper $(\mathrm{Cu})$. The high content of $\mathrm{Cu}$ in $\mathrm{PH}$ could be related to the use pesticides and fungicides which contain $\mathrm{Cu}$ (Khabaz \& Meristani, 2013). NRC (2005) reported that $10 \mathrm{mg} \mathrm{cu} / \mathrm{kg}$ in the diet of sheep cause chronic toxicosis. Furthermore, sheep and cattle tend to develop liver lesions when they consume excessive amounts of hydrolyzable tannins (Waghorn et al., 2003). This was supported by Vahmani et al. (2005) who used dry PH up to $6 \%$ in rations of lactating cows over 84 days. Shakeri et al. (2012) reported that feeding PH silage over 6 months does not has any adverse effect on the health status of lactating cattle and fattening calves. Increasing the levels of PBM silage up to $18 \%$ of dietary DM of calves did not change $\mathrm{pH}$, specific gravity, white and red blood cells number and epithelial cells of urine and did not cause hemoglobin uria and hematory (Shakeri et al., 2012). Valizadeh et al. (2010) did not detect any adverse effect of PH up to $30 \%$ in the ration of lambs on general health and hematology during a trial of 90 days. The use of $\mathrm{PH}$ in the diet of sheep can decreased blood urea-N concentration up to $36 \%$ without affecting other blood metabolites (Ghaffari et al., 2014a). Mahdavi et al. (2010) used $\mathrm{PH}$ up to $35 \%$ in the ration of growing lambs over 90 days without negative effects on liver and kidney histology. Moumen et al. (2003) incorporated PH up to $30 \%$ of goats' ration over 174 days without harmful effects on health. While Sedighi-Vesagh et al. (2015) reported increase alanine aminotransferase in blood of goat while these were feeding on PH up to $32 \%$ for 63 days, this indicates some damage in the liver cells. Although pistachio byproducts have a high content of $\mathrm{Cu}$, pistachio by-products can be safely included in diets without harmful consequences on ruminant health. That might be because tannins in $\mathrm{PH}$ bind to cu and decrease its toxic effects. However, the reported studies were based on short-term trials of up to 4 months. Therefore, further studies to investigate the effects of long-term feeding of pistachio leaves on livestock health should be undertaken.

\section{Conclusion}

Pistachio by-products represent potential feed resources for livestock in pistachio producing countries. However, these byproducts are still underutilized for livestock feeding. Studies have been conducted in recent years to investigate the effect of pistachio by-products on livestock performance and product quality. In view of these studies, practical recommendations can be highlighted: i. The chemical composition and digestibility of pistachio by-products are at acceptable levels for moderate incorporation in diets of ruminants $(18-40 \%$ of total dietary DM). However, the variability in the nutritive value of twigs, leaves, hulls and PBM has to be considered.

ii. Pistachio by-products, leaves and hulls are suitable for livestock feeding. However, twigs have high contents of phenolic compounds $(100 \mathrm{~g} / \mathrm{kg} \mathrm{DM})$ while woody shells have very low digestibility $(<22 \%)$, thus would be more effectively utilized as sources of energy or for biogas production.

iii. Pistachio by-products can be used dry or ensiled. Therefore, recommendations on appropriate storage methods should considering conditions within farming systems.

iv. The content of cuin pistachio by-products is 1.5 times higher than the toxic level recommended for ruminants. Therefore, the effect of feeding pistachio by-products over long periods on livestock health should be studied.

v. Further studies on the effects of using pistachio byproducts on need to be carried out.

vi. The effect of pistachio by-products on quality of milk and meat, reproductive performance, wool and hair yield and quality of ruminants require further studies.

vii. Utilization of pistachio by-products for livestock feeding by farmers is currently reported to be low. Thus, the determinants and drivers of their utilization by farmers need to be identified.

\section{Conflict of Interest}

Authors would hereby like to declare that there is no conflict of interests that could possibly arise.

\section{References}

ACSAD (1988) Characters of the most important varieties of pistachio grown in Aleppo Province. ACSAD, Damascus.

Acton A (2012) Issues in Global Environment: Pollution and Waste Management: 2011 Edition. Scholarly Editions, Atlanta.

Assimakopoulou A, Nifakos K, Salmas I, Alyfantis N (2013) Preliminary study of the nutritional status of pistachio in Aegina, Greece. Communications in Soil Science and Plant Analysis 44: 356-365. 
Babaei, Y, Rouzbehan Y, Alipour D (2015) Effect of rumen bacteria from sheep adapted to a tanninferous diet on in vitro fermentation parameters of pistachio hulls using bovine inoculum. Iranian Journal of Veterinary Research 16: 357-62.

Bagheripour, E, Rouzbahan Y, Aipour D(2008) Effect of ensiling, drying and addition of polyethemen glycol on in vitro gas production of pistachio by products. Animal Feed Science and Technology 146: 327-36.

Bagheripour E, Rouzbehan Y, Alipour D (2012) Chemical composition and digestibility of ensiled pistachio by-products. In: Kuoppala K, Rinne M, Vanhatalo A (Eds) XVI International Silage Conference, Hämeenlinna, Finland: 238-239.

Bakhshizadeh S, Taghizadeh A, Janmohammadi H, Alijani S (2014) Chemical composition and the nutritive value of pistachio epicarp (in situ degradation and in vitro gas production techniques). Veterinary Research Forum 5: 43-47.

Behgar M, Valizadeh R, Naserian A, Eftekhari Shahroudi F, Nassiri M (2008) Correlation between the physical and chemical properties of some forages and non-forage fiber source. Journal of Animal and Veterinary Advances 8: 2280-85.

Boga M, Guven I, Atalay A, Kaya E (2013) Effect of varieties on potential nutritive value of pistachio hulls. Journal of the Faculty of Veterinary Medicine, Kafkas University 19: 699-703.

Bohluli A, Naserian A, Valizadeh R (2010) The chemical composition and ruminal disappearance of pistachio by-product. Iranian Journal of Animal Science Research 2: 69-80.

ÇelikI, Demirer G (2015) Biogas production from pistachio (Pistacia vera L.) processing waste. Biocatalysis and Agricultural Biotechnology 4: 767-72.

Delgado-Pertinez M, Chesson A, Provan G, Garrido A, GomezCabrera A (1998) Effect of different drying systems for the conservation of olive leaves on their nutritive value for ruminants. Annales de zootechnie, INRA/EDP Sciences 47: 141-150.

Denek N, Aydin S, Can A (2017) The effects of dried pistachio (Pistachio vera L.) by-product addition on corn silage fermentation and in vitro methane production. Journal of Applied Animal Research 1: 185-189.

Dreher M (2012) Pistachio nuts: composition and potential health benefits. Nutrition Reviews 70: 234-40.

Elahi M, Salehi A, Salem A (2012) Effect of molasses and polyethylene glycol on dry matter degradability of pistachio by products silage in cows. In: In Kuoppala K, Rinne M, Vanhatalo
A (Eds) XVI International Silage Conference, Hämeenlinna, Finland: 236-237.

FAO (2014)FOA Stat, Pistachio Production. Available on

http://faostat3.fao.org/browse/Q/QC/E, accessed on 01 May 2017.

Foroogh-Ameri N (2004) A Seurvey on posibbility of use ensailed pistachio by-products in milking cows nutrition. Available on http://agris.fao.org/agris-search/search.do?recordID= IR2010036260

Fuller M(2004) Encyclopedia of Farm Animal Nutrition. CABI publishing, London.

Ghaffari M, Tahmasbi A, Khorvash A, Naserian A, Ghaffari A, Valizadeh R(2014a) Effects of pistachio by-products in replacement of alfalfa hay on populations of rumen bacteria involved in biohydrogenation and fermentative parameters in the rumen of sheep. Journal of Animal Physiology and Animal Nutrition 98: 578-586.

Ghaffari M, Tahmasbi A, Khorvash M, Naserian A, Reza Vakili A (2014 b) Effects of pistachio by-products in replacement of alfalfa hay on ruminal fermentation, blood metabolites, and milk fatty acid composition in saanen dairy goats fed a diet containing fish oil. Journal of Applied Animal Research 42: 186-93.

Ghasemi S, Naserian A, Valizadeh R, Reza Vakili A, Behgar M, Tahmasebi A, Ghovvati S (2012 a) Partial and total substitution of alfalfa hay by pistachio byproduct modulated the counts of selected cellulolytic ruminal bacteria attached to alfalfa hay in sheep. Livestock Science 150: 342-48.

Ghasemi S, Naserian A, Valizadeh R, Tahmasebi A, Reza Vakili A, Behgar M, Ghovvatia S(2012 b) Inclusion of pistachio hulls as a replacement for alfalfa hay in the diet of sheep causes a shift in the rumen cellulolytic bacterial population. Small Ruminant Research 104: 94-98.

Ghasemi S, Naserian A, Valizadeh R, Tahmasebi, M, VakiliR, Behgar M (2012 c) Effects of pistachio by-product in replacement of lucerne hay on microbial protein synthesis and fermentative parameters in the rumen of sheep. Animal Production Science 52: 1052-1057.

Gholiezade H, Naserian A, Valizadeh R, Tahmasbi A, Sari M (2009) Effect of different sources of supplemental protein on performance and on ruminal $\mathrm{pH}$ and $\mathrm{N}-\mathrm{NH} 3$ of holstein dairy cows. Available on

http://profdoc.um.ac.ir/articles/a/1013991.doc accessed on 01 May 2017. 
Gholizadeh H, Naserian A, Valizadeh R, Tahmasbi A (2010) Effect of feeding pistachio by-product on performance and blood metabolites in Holstein dairy cows. International Journal of Agriculture and Biology 12: 867-870.

Jolazadeh A, Dehghan-Banadaky M (2015) Effects of soybean meal treated with tannins extracted from pistachio hulls on performance, ruminal fermentation, blood metabolites and nutrient digestion of Holstein. Animal Feed Science and Technology 203: 33-40.

Kearl L (1982) Nutrient Requirements of Ruminants in Developing Countries. International Feedstuffs Institute, Utah.

Khabaz K, Meristani H (2013) Pistachio Tree. General Commission of Scientific Agricultural Research, Damascus.

Kumar R, Vaithiyanathan S (1990) Occurrence, nutritional significance and effect on animal productivity of tannins in tree leaves. Animal Feed Science and Technology 30: 21-38.

Labavitch J, Heinz C, Rae H, Alkader A (1982) Physiological and compositional changes associated with maturation of Kerman pistachio nuts. Journal of the American Society of Horticulture Science 107: 688-92.

Mahdavi A, Zaghari M, Zahedifar M, Nikkhah A, Alemi F, Hosseini A, Mirabdolbaghi Z, Lotfolahiyan H (2010) The effects of dried pistachio epicarp on lamb performance. Advances in Animal Biosciences 1: 236-236.

Makkar H(2003a) Quantification of Tannins in Tree and Shrub Foliage. A laboratory Manual. Kluwer academic publishers, Dordrecht.

Makkar H (2003b) Effects and fate of tannins in ruminant animals, adaptation to tannins, and strategies to overcome detrimental effects of feeding tannin-rich feeds. Small Ruminant Research 49: 241-256.

Mokhtarpour A, Naserian A, Pourmollae F, Ghaffari M (2016) Effect of treating alfalfa silage with pistachio by-products extract on Saanen dairy goats performance and microbial nitrogen synthesis. Journal of Animal Physiology and Animal Nutrition 100: 758-767.

Mokhtarpour A, Naserian A, Tahmasbi A, Valizadeh R (2012) Effect of feeding pistachio by-products silage supplemented with polyethylene glycol and urea on Holstein dairy cows performance in early lactation. Livestock Science 148: 208-213.

Moradi M, Afzalzadeh A, Behgar M, Norouzian M (2015a) Effects of electron beam, $\mathrm{NaOH}$ and urea on chemical composition, phenolic compounds, in situ ruminal degradability and in vitro gas production kinetics of pistachio by-products. Veterinary Research Forum 6:111-117.

Moradi M, Behgar M, Afzalzadeh A, Norouzian M (2015b) Effects of electron irradiation, sodium hydroxide and poly ethylene glycol on the utilization of pistachio by-products by Zandi male lambs. Small Ruminant Research 127: 1-7.

Morales R, Ungerfeld E (2015) Use of tannins to improve fatty acids profile of meat and milk quality in ruminants: a review. Chilean Journal of Agricultural Research 75: 239-248.

Moumen S, Zahedifer M, Salehi M (2003) The effect of different levels pistachio by-products and its tannins on growth and Cashmere production of Raieni goats. Pajouhsh \& Sazandegi 65: $92-102$.

Naserian A, Staples C, Ghaffari M (2015) Effects of replacing wheat bran by pistachio skins on feed intake, nutrient digestibility, milk yield, milk composition and blood metabolites of dairy Saanen goats. Journal of Animal Physiology and Animal Nutrition 100: $256-63$.

Naserian A, Vahmani R (2005) Effect of feeding pistachio skins on performance of lactating dairy goats. In: Honing Y (Ed.), Book of Abstracts of the 56th Annual Meeting of the European Association for Animal Production, Wageningen Academic Publication, Uppsala.

Norouzian M, Ghiasi S(2012) Carcass performance and meat mineral content in Balouchi lamb fed pistachio by-products. Meat Science 92: 157-159.

NRC (2005) Mineral Tolerance of Animals. National Academy Press, Washington DC.

Razzaghi A, Naserian A, Valizadeh R, Ebrahimi S, Khorrami B, Malekkhahi M, Khiaosaard R (2015) Pomegranate seed pulp, pistachio hulls, and Tomato pomace as replacement of wheat bran increased milk conjugated linoleic acid concentrations without adverse effects on ruminal fermentation and performance of Saanen dairy goats. Animal Feed Science and Technology 210: 46-55.

Rezaeenia A, Naserian A, Valizadeh R, Tahmasbi A (2012) Effect of using different levels of pistachio by-products silage on composition and blood parameters of Holstein dairy cows African Journal of Biotechnology 11: 6192-96.

Roosta H, Mohammadi Z (2013) Improvement of some nut quality factors by manure, ammonium, and iron application in alkaline soil pistachio orchards. Journal of Plant Nutrition 36: 691-701. 
Salehi M, Mirzaei F (2011) Effects of different levels of feeding of pistachio epicarp silage on wool characteristics of growing Afshari Lambs. Journal of Animal Science Advances 1: 119-122.

Salehi M, Mahdavi A, Zahedifar M(2009) Effects of different levels of dried pistachio epicarp on wool chareceristics of growing Afshari lambs. Krmica 4: 191-197.

Sedighi-Vesagh R, Naserian A, Ghaffari M, Petit H (2015) Effects of pistachio by-products on digestibility, milk production, milk fatty acid profile and blood metabolites in Saanen dairy goats. Journal of Animal Physiology and Animal Nutrition 10: 777-787.

Shakeri P (2016) Pistachio by-Product as an alternative forage source for male lambs: effects on performance, blood metabolites, and urine characteristics. Animal Feed Science and Technology 211: 92-99.

Shakeri P, Riasi A, Alikhani M(2014) Effects of Long period feeding pistachio by-product silage on chewing activity, nutrient digestibility and ruminal fermentation parameters of Holstein male calves. Animal 8: 1826-1831.

Shakeri P, Riasi A, Alikhani M, Fazaeli H, Ghorbani G(2013) Effects of feeding pistachio by-products silage on growth performance, serum metabolites and urine characteristics in Holstein male calves. Journal of Animal Physiology and Animal Nutrition 97: 1022-1029.

Shakeri P, Riasi P, Alikhani M, Ghorbani G, Fazaeli G (2012) The effects of pistachio by-product silage feeding on microbial protein synthesis and kidneys function of Holstein fattening bulls. Animal Science Researches (Faculty of Agriculture, University of Tabriz) 21: 97-110.

Sharifabadi H, Naserian A (2014) Growth performance and nitrogen retention in lambs fed diets containing two different levels of crude protein supplementation with pistachio byproduct extract as a source of tannins. Research Options in Animal and Visionary Sciences 4: 273-280.

Soltaninezhad B, Dayani O, Khezri A, Tahmasbi R (2016) Performance and carcass characteristics in fattening lambs feed diets with different levels of pistachio by-products silage with wasted date. Small Ruminant Research 137: 177-182.

Tahmourespour A, Tabatabaee N, Khalkhali H, Amini I (2016) Tannic acid degradation by Klebsiella strains isolated from goat feces. Iranian Journal of Microbiology 8: 14-20.

Terrilla T, Douglasa T, Footea A, Purchasa R, Wilsona G, Barryal $\mathrm{T}(1992)$ Effect of condensed tannins upon body growth, wool growth and rumen metabolism in sheep grazing Sulla (Hedysarum coronarium) and perennial pasture. The Journal of Agricultural Science 119: 265-273.

Vahmani P, Naserian A, Arshami J, Nasirimoghadam H(2005) Effect of feeding pistachio hulls on performance of lactating cows. In Honing Y (Ed.), Book of Abstracts of the 56th Annual Meeting of the European Association for Animal Production, Wageningen Academic Pub, Uppsala.

Vahmani P, Naserian A, Redazadeh R, Nasirimoghadan H(2006) Nutritive value of pistachio by products and there effects on Holstein cows in med lactation. Journal of Agriculture Science and Technology 20: 210-213.

Valizadeh R, Naserian A, Vahmani P (2009) Influence of drying and ensiling pistachio by-products with urea and molasses on their chemical composition, tannin content and rumen degradability parameters. Journal of Animal and Veterinary Advances 8: 23632368 .

Valizadeh R, Norouzian M, Salemi M, Ghiasi G, Yari M(2010) Effect of feeding pistachio by products on hematology and performance of Balochi lambs. Journal of Animal Veterinary Advances 9: 1115-1119.

Valizadeh R, Sobhanirad S (2009) The potential of agro-Industrial by-products as feed sources for livestock in Khorasan Razavi province of Iran. Journal of Animal and Veterinary Advances 8: 2375-2379.

Waghorn G, Warren C, McNabb C (2003) Consequences of plant phenolic compounds for productivity and health of ruminants. Proceeding of the Nutrition Society 62: 383-392. 